\title{
Maiakóvski e o Teatro de Formas Animadas
}

\author{
Valmor Beltrame (Nini) \\ Universidade do Estado de Santa Catarina
}

\section{Introdução}

Os últimos anos do século XIX e os primeiros do século XX são marcados pelo crescente interesse de dramaturgos e encenadores pela marionete. A marionetização do ator, a substituição do ator por bonecos, por formas, a humanização de objetos são discussões que animam a produção teatral. Em tomo dessa polêmica estão artistas que negam o teatro burguês, a estética do romantismo, do melodrama e do realismo, enquanto correntes artísticas e defendem o simbolismo como arte. Tal interesse aparece de forma visível em duas direções; a marionete como referência para o comportamento do ator em cena e o teatro de marionetes como gênero artístico ou, de outra maneira, o fascínio pela marionetização do trabalho do ator e experimentações em tom da humanização de objetos.

Encenadores e dramaturgos, decepcionados com a atuação dos atores, seu histrionismo, excessos, caretas e seus condicionamentos psicofísicos expressam a necessidade do ator assumir outro comportamento em cena e apontam a marionete como referência para seu trabalho. Acreditam que marionete pode expressar os estados da alma ocultos e impalpáveis, possibilitando conhecer e mostrar as sensações transcendentais. Na raiz dessa discussão está a defasado controle sobra o trabalhado ator a ser efetuado pelo diretor e a negação do espontaneísmo, do maneirismo, do vedetismo, predominantes c. comportamento dos atores na época. A teatralização do teatro, a necessidade de afirmar a função do diretor como o maior responsável pela criação do. espetáculo teatral, incumbindo-o da preparação psicofísica dos elencos, são preocupações que permeiam essa discussão.

Basta lembrar as contribuições de Kleist, Maeterlinck, Jarry e Craig para situar a inquietação de alguns artistas e teóricos do teatro deste tempo em relação a arte produzida na época ${ }^{1}$.

\footnotetext{
${ }^{1}$ Em "Sobre o Teatro de Marionetes", Herick Von Kleist apresenta um texto polêmico por defender que o belo está no artificial e no autômato. Maeterlinck, escreveu nove peças para marionetes na perspectiva de uma estética simbolista. No estudo "Menus Propus - Le Théâtre" propôe a supressão do ser humano da cena e em seu lugar a presença de sombras, reflexos, formas simbólicas com $\neg$ aparência de vida, sem ter vida. Jarry, ao fazer a estréia de "Ubu Rei" em Paris
} 
$\mathrm{Na}$ Rússia do princípio do século, este fenômeno também ganha visibilidade seja no interior da obra dos cubo-futuristas através da linguagem Zaun $^{2}$, como também em diversas expressões artísticas que recorrem às manifestações da cultura popular local. O teatro, e especial o teatro de Maiakóvski, recria diferentes expressões da cultura popular russa, dentre elas o teatro de bonecos conhecido como Petruchka, bastante vivo nas feiras e periferias das grandes cidades.

As publicações a respeito das encenações das suas peças quase todas dirigidas por Meyerhold ${ }^{3}$, sugerem que o uso da linguagem do teatro de animação aí contido é tão rico e instigante quanto o que se apresenta nos textos dramáticos. Porém, os registros fotográficos e descrições sobre tais encenações são escassos no ocidente e não são relativos a todos os textos escritos. Por isso, os textos dramáticos são a maior referência para o presente estudo.

A análise dos textos dramáticos de Maiakóvski, sob a ótica da linguagem do teatro de animação evidencia três aspectos fundamentais:

a) a presença de "nomes falantes" na denominação de personagens de algumas peças, que remetem, assim, às formas de arte popular, notadamente ao circo e ao teatro de bonecos;

b) o boneco com alegoria, onde o poeta faz hipérbole e ridicularização de comportamentos sociais e simultaneamente sintetiza o sentimento popular sobre personalidades russas;

c) a "humanização" dos objetos, quando realça a possível vida existente nos objetos e a inumanidade dos homens.

Antes de analisá-las faz-se necessário discutir algumas características desta linguagem artística, o teatro de bonecos.

em 1896 como atores usando máscaras apresenta personagens marionetizadas, e os atores com gestualidade próxima ao do boneco. Craig, em "Da Arte do Teatro", em 1906, propõe a substituição do ator e sua interpretação realista/naturalista pela Supermarionete: o ator inteiramente coberto pela máscara, apresentaria a personagem sem deixar transparecer ou revelar traços da sua própria personal idade de ator.

${ }^{2}$ Linguagem Zaun ou Transmental, utilizada pelos artistas russos conhecidos como cubo-futuristas que desarticula o significante do significado, que faz o desmembramento do sentido e significado. Maiakówski, no princípio de suas atividades artísticas estava vinculado a este movimento. ${ }^{3}$ Vsiévolod Meyerhold (1874-1940) Diretor, ator e teórico de teatro russo. Fez parte do Teatro de Arte de Moscou onde trabalhou com Stanislavski. Em 1917, entusiasmado com a Revolução proclama Outubro Teatral, propondo a revolução artística e política no teatro. Nesse período organizou os famosos espetáculos de massa. Foi o grande companheiro de Maiakóvski, dirigindo seus textos e tendo-o como diretor assistente. Em 1937, sob as ordens de Stalin, a polícia fecha seu teatro. É preso em 1939 e fuzilado no dia 02 de fevereiro de 1940 (Hormigon, 1992, p.21-36). 


\section{Teatro de animação}

Atualmente, várias nomenclaturas são adotadas para referir-se à linguagem do teatro de animação: teatro de bonecos, teatro de fantoches, teatro de marionetes, teatro de objetos, teatro de formas animadas, teatro de figura.

Cada uma destas denominações poderá apresentar especificidades técnicas c estéticas quando comparadas entre si, porém, todas dizem respeito ao que se pode chamar teatro de animação, isto é, um teatro que anima o inanimado. Têm-se $\neg$ como princípio fundamental dar vida, ânima, ao objeto, à forma, ou ao boneco simulacro do humano. Para isso, a característica fundamental desta arte é $\neg$ presença do objeto a ser animado e do ator-animador que dá vida a esta forma.

Assim, “... o teatro de bonecos é uma arte teatral cuja característica. principal que o diferencia do teatro de atores é o fato de que o objeto (boneco) necessita de fontes físicas e de poderes vocal e motor que estão fora ...: si'(Jurkowski, 1990, p.75). Ou seja, a personagem no teatro de bonecos, atores que protagonizam as cenas nesta arte, têm dependência direta de terceiros para adquirirem vida. Ao dizer que os poderes vocal e motor da personagem estão fora do objeto, destaca a incondicional idade da atuação do ator-animado.

No entanto, Amaral acrescenta outros elementos fundamentais na identificação das características desta linguagem artística: "Boneco é o termo zusado para designar um objeto que, representando a figura humana ou animal é dramaticamente animado diante de um público" (1991, p.69). Além -movimento da forma animada e da presença do ator-animador mencionados por Jurkowski, Amaral acrescenta a exigência do tratamento dramático na animação, bem como aponta para a necessidade da presença do público. Portanto, dois elementos fundamentais para a realização do ato teatral.

Por objeto animado dramaticamente não se pode entender a forma animada possuída apenas de movimento. Isso não é suficiente para que esteja $\neg$ vivo. O boneco está vivo sobretudo quando age de forma a dar ao público a -ilusão de que pensa, e tem autonomia em relação aos seus atos, ações e emoções. $\mathrm{O}$ boneco pensa quando se comporta como personagem, quando tem vida própria. $\neg$

$\mathrm{O}$ bonequeiro pode utilizar diversas maneiras para chegar a isso e uma delas é privilegiar a ação do boneco na encenação. Na medida em que a ação do boneco se completa com o texto, ganha vida, seu caráter se evidencia e a relação com a platéia se estabelece. Os solilóquios, os discursos verbais destituídos de ação dramática traem a condição do boneco. Quando o texto 
diz tudo e não permite que as palavras pronunciadas se materializem de certa forma em gestos, instala-se um vazio na comunicação. Assim, o boneco vivo é boneco em movimento, com ação física reveladora do caráter da personagem, que representa.

A vocação do boneco é realizar o inusitado, o impossível, o inimaginável do ponto de vista da ação física. Como diz o marionetista russo Obravtsov, fundamental é perceber que “... o que pode ser expressado por um boneco, não pode ser expressado por um ator" (1950, p.117). Quando o boneco não assume a condição de boneco ou não dá proporções aos gestos e movimentos maiores que as reais; quando não se utiliza dos excessos, do exagero, quando o boneco se limita a imitar o ator, a linguagem do teatro de animação não se efetiva.

Outro aspecto que caracteriza o teatro de animação, a construção das personagens, é que estas não precisam necessariamente ter a aparência de seres humanos. É freqüente encontrar personagens antropomorfas com traços sintéticos, que remetem à forma humana. No entanto, também tem sido comum a personagem apresentar uma forma inusitada, destituída de traços físicos humanos, uma forma confeccionada especialmente para esta finalidade, ou ser um objeto do cotidiano. Por isso, estas personagens são esquemáticas, possuem traços definidos, claros, porém, não têm o que no teatro se denomina de "aprofundamento psicológico". Estão mais próximas do esquema, da personagem tipificada.

A apresentação destas características e peculiaridades da arte do teatro de bonecos toma-se fundamental para este estudo, uma vez que muitas delas estarão presentes na obra dramatúrgica de Maiakóvski analisada a seguir.

\section{Os nomes falantes}

As diversas maneiras de caracterizar e definir a personagem no texto dramático compreendem, basicamente, traços físicos, sociais, ou psicológicos. O dramaturgo procura destacar traços em cada uma delas, buscando, além de identificá-la, diferenciá-la das outras. Às vezes, há a predominância de um desses aspectos na definição do caráter da personagem, mas quase sempre o somatório desses aspectos dá sustentação, tomando-a crível, permitindo, dessa maneira, reconhecer seus desejos e vontades ${ }^{4}$.

\footnotetext{
${ }^{4}$ Renata Pallottini, em seu livro, "Dramaturgia: a construção da personagem”, dedica um capítulo ao estudo das diversas formas de caracterização da personagem dramática.
} 
Em certos momentos da história da dramaturgia é possível perceber a predominância de formas peculiares na caracterização das personagens. Por exemplo, as personagens nos textos naturalistas, vão, em sua maioria, destacar traços psicológicos; já as personagens do teatro de feira, da rua, no teatro popular, são comum ente esquemático, sintéticos, o que permite dizer que há uma predominância de características sociais. As personagens são normalmente típicas: soldado, amante, a bela, a má, o trabalhador, o patrão etc...

No teatro de bonecos popular do Brasil há uma peculiar forma de caracterização que se dá através do nome da personagem. O nome já é definidor do caráter e do seu comportamento. Os nomes sintetizam sua forma de ser. Para Ripellino, referindo-se às personagens da peça "Os Banhos" de Maiakovski, são "nomes falantes" (1986, p.198).

No Mamulengo ${ }^{5}$, teatro de bonecos popular da região do Pernambuco, a personagem central do trabalho de muitos mamulengueiros é conhecida como Professor Tiridá. Trata-se de um justiceiro, esperto, malandro que ao mesmo tempo ajuda os pobres e é inconformado com a concentração de riqueza nas mãos de poucos. Portanto, é o que tira e dá, por isso, TIRIDÁ.

Outra personagem bastante conhecida é Maria Favoráve (corruptela de favorável) para designar a moça que "dança com todos", disponível, sempre convidada a dançar com alguma personagem nas interrupções das cenas. É possível identificar, ainda, personagens como Zé das Moças, que designa querido: Benedito, o negro; Cabo Setenta, “... delegado de roubos... de vigilância de costumes e de brigas de galo...” ou Afonso Gostoso “... moço delicado! Moço suspeitoso! As mulheres são loucas por esse moço!” (Borba Filho, 1987, p.179)

Estes nomes e de outras personagens podem ser encontrados nas peças de mamulengueiros nordestinos recolhidas por Hermilo Borba Filho.

O "nome falante" é uma forma sintética de caracterização da personagem. O nome contribui para identificar seu caráter e comportamento A explicitação do seu nome é suficiente para diferenciar sua maneira de ser das demais personagens.

Maiakóvski se utiliza deste recurso dos "nomes falantes" na peça Os Banhos, por certo inspirado no Petruchka, herói popular do teatro de bonecos russo. Historiadores como o francês Jacques Chesnais (1980) e o polonês Ma-

\footnotetext{
${ }^{5} \mathrm{O}$ teatro de bonecos popular do Brasil, mais conhecido como Mamulengo, refere-se à manifestação na região do Estado do Pernambuco. Já no Rio Grande do Norte é chamado Calunga, no Ceará é conhecido como Babau ou Mané gostoso. No Maranhão e Paraíba é João Redondo. Existem denominações diversas para essa expressão dramática popular que mantém características similares.
} 
rek Wazkiel (1997) afirmam que o teatro de bonecos é introduzido na Rússia pelos alemães. Dizem ainda que nasceu no século XVII e "sob o reinado do Imperador Alexis, foi proibido de 1648 a 1672. Petruchka é um personagem extremamente popular, vulgar em suas palavras e em seus atos. Faz parte da família dos Polichinellos e é quase exclusivamente representado por bonecos de luva" (Chesnais, 1980, p.165).

Vale destacar que tanto o Petruchka, quanto as personagens do nosso Mamulengo, assim como os outros heróis populares do teatro de bonecos de outros países, mantêm traços comuns tais como: são bonecos de luva, o que no Brasil comum ente se chama de fantoche; em seus aspectos físicos destacam-se narigões, bocarras por vezes apenas pintadas com traços amplos, exagerados, sem preocupações realistas; além da origem popular comum a personagem central possui caráter irreverente, é justiceiro, têm um vocabulário recheado de palavrões, questiona as autoridades constituídas e resolve seus conflitos com surras e pauladas. A palavra tem grande ênfase neste tipo de teatro que representa comédias improvisadas a partir de um roteiro que se atualiza e modifica com os acontecimentos cotidianos e intervenções das platéias. O bonequeiro ao interpretar durante toda a sua vida a mesma personagem, vai ampliando o repertório de gestos, ações e falas desta personagem que ganha cada vez mais autonomia e força, solidificando-se como personagem na prática de representar.

Na denominação das personagens da peça "Os Banhos", fica evidente a utilização do recurso de "nomes falantes". A apresentação das personagens desta peça, presente no estudo: “Os Banhos: uma poética em cena”, de Reni

6 Em muitos países ainda existe um teatro de bonecos popular, conhecido pelo nome da sua personagem central: VASILACHE, herói popular do teatro de bonecos Romeno, KARAGOZ, figura central do teatro de sombras popular da Turquia e Grécia. PUNCH e JUDY, casal, personagens centrais do teatro de bonecos inglês que aparece em Londres pela primeira vez em 1662, com o nome de Pulcinella. TCHANTCI-IES, herói popular do teatro de marionetes da região de Liége, Bélgica. KASPEREK, herói popular do teatro de marionetes da República Tcheca. PULCINELLA, pai da maioria dos heróis populares, remanescente da commédia dell'arte. Napolitano de origem, sabe-se que provém das farsas atelanas. KASPERLE, herói popular do teatro de bonecos alemão, parente próximo do Pulcinclla italiano e do Punch inglês, muito popular no início do século XIX. POLISZYNEL, herói popular do teatro de bonecos francês, atuante desde 1630. A partir da revolução francesa não se tem mais notícias de suas atuações. Reaparece nas ruas e feiras de Lion e Paris a partir do século XIX substituído pelo GUIGNOL. JAN KLASSEN, herói popular do teatro de marionetes holandês, conhecido já a partir da segunda metade do século XVII. (Extraído de textos de Marek Wazkliel publicados nas revistas da UNIMA Espanha, TITEREANDO, números 50 a 63). 
Chaves Cardoso revela que Maiakóvski utilizou abundamente deste recurso .

"A personagem Pobiedonóssikov junta ironicamente "pobieda" (vitória) ao afetuoso "nóssik" (narizinho) recordando ao mesmo tempo o sobrenome do retrógrado Pobiedonóstzev, inspirador da polícia de Alexandre III. A pesquisadora acrescenta: "Pobiedonóssikov é um palhaço de uma repartição burocrática apresentada como circo: às vezes um circo do horror, com toda a burocracia emperrando qualquer iniciativa, onde os peticionários, de tanto esperar por uma resposta para seus pedidos, petrificam-se, são representados por manequins; Pobiedonóssikov seria então: aquele que carrega a vitória no nariz" (Cardoso, 1990, p.205).

O nome da personagem Pólia "é um tratamento afetivo, um diminutivo de Polina (do francês Pauline). Esta personagem traz em sua fala a seguinte característica: no final de cada oração sempre diz: "Engraçado!" ou "Não é engraçado!" e através disto, ela divide o mundo em o que é e o que não é engraçado" (Cardoso, 1990, p.206). Camarada Momientá1 nikov, o servidor dos burocratas é um repórter e remete a momento, instante. Camarada Optimístienko, secretário de Pobiedonóssikov, tem na raiz do seu nome, otimista. Camarada Belvedónski, retratista, tem por sua vez a referência de belo, bela vista. Camarada Vielossipiédkin, ex-cavalariano ligeiro, guarda popular, tem como referência o nome russo proveniente de velocipiéd, velocípede, bicicleta, e indica duas características básicas da personagem: a rapidez e a esperteza. Camarada Underton, a datilógrafa. Underton é a marca de máquina de escrever, famosa em 1930. Segundo Reni C. Cardoso, esse nome falante poderia ser traduzi de por Camarada Remington. Camarada Tchudakóv, o inventor. Deriva de tchudák. que significa esquisito, excêntrico e também pode ser tchudo, milagre, maravilha

Pont Kitsch, um estrangeiro ávido por saber dos operários russos come inventaram a máquina do futuro. Talvez seja necessário evidenciar que “...o nome Kitsch está certamente ligado ao substantivo alemão que designa os objetos de péssimo gosto... as palavras russas são ajuntadas de modo a transmitir por semelhanças fonéticas, locuções inglesas" (Ripellino, 1986, p.198).

\footnotetext{
7 “Os Banhos: uma poética em cena”, a leitura desta tese é fundamental para a compreensão do teatral de Maiakóvski. Sua importância não reside somente no fato de apresentar uma análise exaustiva _ peça “Os Banhos”, também faz ampla contextualização do período vivido pelo poeta, além _ trabalhar sua obra como conjunto, indissociando teatro e literatura. Destaca-se ainda a documentação fotográfica das encenações das peças de Maiakóvski dirigidas por Meyerhold.
} 
Mezaliánsova, personagem na qual Maiakóvski critica a postura oportunista, burocratizada e, sobretudo colonizada das pessoas responsáveis por relações culturais internacionais, tem na origem do seu nome a expressão francesa "“"ésalliance"" que significa casamento com pessoa de origem socialmente inferior. Maiakóvski transforma "Mésalliance" em Mezaliánsova.

Nestas dez personagens da peça "Os Banhos" o poeta recorre ao uso dos "nomes falantes" para melhor caracterizá-las, oferecendo ao público informações claras sobre o modo de ser da personagem.

Este mesmo procedimento aparece na peça "O Percevejo". A personagem central da peça, Prissipkine, Pedro Skripkine, ex-operário, ex $\neg$ membro do Partido e noivo, na peça nega sua origem de classe. A personagem muda o nome de Prissipkine para Skripkine, e faz isso para tomar-se mais nobre. É que Prissypat vem do verbo russo polvilhar, enquanto que Skripkine é uma palavra derivada do violino (O’Neill, s./d, p.23). Essa mudança de nome de Prissipkine (talco, polvilhar) para Skripkine (violino) indica que a personagem, antes, era ligada ao mundo do trabalho. Agora com o outro nome, não pertence mais a este mundo, mas ao da aristocracia, é erudito, fino, delicado. Ou seja, o nome indica a nova condição da personagem.

Para o italiano Rippelino, a tendência para designar os personagens com denominações significativas chegou a Maiakóvski por meio dos clássicos: "encontram-se, como se sabe, esplêndidos exemplos em Gogol, e Súkhovo $\neg$ Kobílin e ainda mais cedo, nas comédias do século XVIII de Fonvizin. Longas listas de divertidos nomes falantes ornam os argutos cadernos do humorismo soviético Iliá III" (1986, p.199).

Sem dúvida as comédias antigas e cadernos de humor podem ter influenciado o poeta russo no uso dos "nomes falantes". Porém, não é possível omitir a referência do Petruchka somando-se a essas influências. Isso se deve ao interesse de Maiakóvski pelas diversas formas de expressões artísticas populares, notodamente ao teatro de bonecos e à arte circense de onde extraiu técnicas e recursos incluídos nos seus textos dramáticos e encenações feitas conjuntamente com Meyerhold.

Jurkovski diz que, no século XIX, em muitas regiões da Europa, era comum a existência de números artísticos com teatro de bonecos dentro da programação dos circos. Muitos espetáculos de teatro de bonecos popular também apresentavam, no final da representação, números com "bonecos de circo" e, criavam assim, um tipo especial de teatro, o teatro de bonecos de variedade (1990, p.72).

Maiakóvski, poeta futurista sabia reunir elementos aparentemente 
contraditórios como, seres abstratos, autômatos, truques estilísticos, tramas sonoras, plasticidade gestual, com números circenses, bonecos e outras expressões recuperadas das manifestações populares russas.

São valiosas as informações e memórias de Sergel Obraztsov , contida em seu livro "Mi Profesión". Conta que ele e outros artistas russos, durante os anos de 1920 a 1923 trabalharam na identificação de artistas que atuavam com teatro de bonecos nas feiras e nas periferias das grandes cidades russas. Menciona que, no ano de 1923, encontrou 'Ivan Afinoguénovich Záitsev e Ana Dmítrievna, los últimos mohicanos dei teatro de feria popular" com quem passou a trabalhar no Teatro Central de Munecos (1950, p.117).

É possível continuar apresentando evidências da proximidade dos "nomes falantes" com o teatro de bonecos popular. Porém os dados apresentados já evidenciam como o poeta russo se aproximava das artes populares e percebia, nestas formas de expressão, a capacidade de síntese e comunicação direta com a platéia e assim intertextualizava estes saberes populares com sua obra. Interessa destacar, ainda, que Maiakóvski, utilizava este recurso para dar vida às suas personagens cujos nomes trazem consigo parte da crítica e ironia que $\neg$ fazia em relação ao comportamento dos burocratas que ocupam cargos novo governo e seu afastamento dos sonhos e expectativas do povo russo.

\section{O boneco como alegoria}

É interessante observar que o teatro contemporâneo feito por atores apresenta, com freqüência, cenas onde são utilizados recursos do teatro de animação. É comum encontrar em espetáculos, ora uma cena com personagem mascarada, ora uma personagem mitológica ou fantástica a ser representa por uma forma animada ou boneco, por vezes, uma cena com as técnicas $\neg$ teatro de sombras.

No entanto, vale destacar que o uso de tais recursos está mais direcionado no sentido de dar certa dinâmica ao espetáculo, criando clima ou mesmo objetivando resolver certos problemas técnicos como a caracterização física dos personagens, do que a experimentar ou trabalhar a linguagem espec do teatro de animação.

O boneco presente na cena deste tipo de espetáculo, mais de persona-

8 Obraztsov, um dos mais conhecidos marionetistas russos, nasceu em Moscou, em 1901, foi inicialmente ator profissional, mas logo optou pelo trabalho com bonecos. Foi diretor do Teatro Central de Bonecos em Moscou e faleceu em 1993. 
gem, apresenta-se como alegoria, como representação sintética simbolizando determinada personagem ou sentimento.

Se essa prática é comum atualmente e para alguns apresenta-se como procedimento inovador no teatro contemporâneo, vale lembrar que Maiakóvski já fazia isso em "Moscou em Chamas" escrita em 1930. Na primeira parte desta peça, há o momento em que se destaca a festa no Palácio de Inverno da monarquia russa. O dramaturgo detalha a cena apresentando situações, personagens presentes e através de rubricas descreve: “O cvzarzinho, a czarina e os ministros aparecem no palco. Um anão de circo, bem magro, representa o czar; a czarina é representada por um enorme boneco cujo pescoço mede cerca de 1,5m. Esse boneco, construído sobre uma grande estrutura é movido por um ator nela oculto".

A apresentação da czarina como boneco-máscara lembra, quanto a sua estrutura, os conhecidos bonecos gigantes da cidade de Olinda em Pernambuco que saem animando o carnaval de rua da cidade. Lembram também a figura de Maricota, personagem do Boi-de-Mamão de Santa Catarina. Trata $\neg$ sse de um boneco-máscara, com um ator dentro da sua estrutura, que dança e caminha pelo espaço. O detalhe relativo ao pescoço, medir um metro e meio de comprimento, lembra certas cenas e personagens do teatro popular onde o boneco ao encontrar-se numa situação que lhe desperta curiosidade, não se desloca até o local de interesse. Imobilizado, o pescoço estica, cresce e vai até o local. Construído com um mecanismo simples permite ao ator-animador, dentro do boneco, fazer o pescoço aumentar e diminuir de tamanho, provocando o riso na platéia.

$\mathrm{O}$ uso que se faz do boneco nesta cena está inteiramente ligado a perspectiva de hiperbolizar o gesto, não limitando-se assim a imitar o ator. A desproporcional idade do pescoço da czarina e o movimento de diminuir e aumentar em um metro e meio o seu comprimento, além de incluir-se dentre as habilidades características do boneco, remete à ridicularização da personalidade histórica que este boneco representa. E para evidenciar ainda mais, Maiakóvski apresenta o czar e a czarina como imagens discrepantes, sem sintonia, provocando o riso, chegando ao grotesco. A boneca czarina é uma alegoria do poder desprestigiado, assim como o czar representado pelo "anão magro" sintetiza a visão e sentimento popular em relação ao poder czarista.

Nesta mesma peça "Moscou em Chamas", há uma cena envolvendo um camponês, jovens sapadores e um Kulak. Segundo nota do tradutor Alexandre 
O’neill, Kulak é o rico camponês proprietário de terras que explorava mão de obra e a partir da revolução, durante o processo de coletivização, se recusava ao trabalho coletivo na fazenda. Esta cena também é reveladora do uso do boneco como recurso estético eventual, como síntese e alegoria de um tipo social - o grande proprietário de terras russo dos anos anteriores à revolução. A transcrição de trecho da cena revela isso claramente:

\section{CAMPONÊS}

O trator semeava e ceifava.

Os resultados eram muito bons

[para Kulak: Seu boca-mole, não gaste suas forças. Afogue $\neg$ se. O Kulak afoga. Balões emergem como um conjunto de bolhas. Sapadores jovens pescam. Eles apanham um boneco - o Kulak. Eles dilaceram o boneco e ensacam os pedaços. Outra sapador apanha refugos de cerca e algumas garrafas e cruzes com sua linha de pesca.

É interessante perceber que o boneco-Kulak é retirado do lixo, do lago poluído, definição clara do sentimento coletivo por este tipo social. A indicação para os sapadores dilacerarem o boneco e ensacarem seus pedaços faz com que o boneco sintetize realidades opostas: o rechaço e morte à figura do grande proprietário de terras russo, explorador de mão-de-obra e a perspectiva de construção de relações distintas das que se evidenciam quotidianamente, ou seja, a coletivização.

As ações realizadas com o boneco-Kulak são repletas de sentidos muito além daquilo que à primeira vista parece. Maiakóvski faz deste boneco ã metáfora do lixo/dejeto/grande proprietário/explorador contrapondo-se a idéia de coletivização/trabalho justo/felicidade.

Vale relembrar a cena da peça "Os Banhos" na qual as personagem que representam o povo são apresentadas como seres petrificados, manequins. Para criticar a demora das solicitações junto às repartições públicas e o descaso das autoridades e burocratas que obrigavam as pessoas a permanecerem longos ᄀtempos nas filas de atendimento, Maiakóvski mistura atores e bonecos/ manequins. No final da cena restam insólitos bonecos, seres humanos imóveis petrificados pela exaustão da espera e desesperança, aguardando resposta que não chegam.

Ao utilizar o recurso do teatro de animação apresentando persona- 
gens, bonecos produz metáforas da realidade, faz representação sintética de v. se sentimentos e desejos, concretiza idéias coletivas. Faz uso da alegoria como cerne do texto dramático possibilitando diversas leituras da ação apresentada.

\section{A "Humanização dos objetos"}

O termo de animação é uma linguagem com especificidades, com certa lógica e procedimentos diferenciados de outras linguagens dramáticas. A presença do objeto na cena é uma das suas características mais fundamentais. No entanto, a expressividade do objeto está relacionada, em certa medida, com sua confecção ou escolha, porém, principalmente com o uso que se faz deste objeto na cena.

Vale reafirmar, o boneco não precisa ter necessariamente a forma humana. Qualquer objeto extraído do cotidiano, quando animado-e animado aqui tem o sentido de animal alma -- quando o ator-animador atua com ele, por certo comunica.

A trajetória de muitos grupos de teatro atualmente no Brasil, vem sendo marcada por este tipo de prática e opção estética. O Grupo X.P.T.O de São Paulo, por exemplo, põe em cena, flores que engravidam, peixes que se apaixonam, sacos de lixo que têm fome e cospem resíduos. O grupo gaúcho Cem Modos, em 1982, fez grande sucesso ao apresentar o espetáculo de estréia do grupo com uma cena que reproduzia a conversa entre duas estudantes universitárias. 'As personagens eram duas pedras sobre as quais se alternava um jogo de luzes que produzia resultados cômicos surpreendentes na platéia. Seria possível apresentar uma quantidade de experiências e criações no teatro contemporâneo, onde a animação de objetos de uso cotidiano dá resultados estéticos e dramáticos eficientes.

Os textos dramáticos de Maiakóvski, Mistério Bufo, O Percevejo e Vladimir Maiakóvski: uma tragédia, são permeados por este tipo de recurso.

Em "Mistério Bufo" isso fica evidente no sexto ato da peça, conhecido como A Terra Prometida, momento em que os objetos passam a assumir comportamentos humanos. Depois da chegada ao local, feito certo reconhecimento do lugar, o Faroleiro, personagem que integra o grupo dos "Sujos" ou trabalhadores, avisa que vê os objetos caminhar, "Os objetos têm pés e mãos. As fábricas estão embandeiradas. Em todos os lugares vejo máquinas descansando”. 
Noutro momento uma rubrica descreve a cena: “... Das vitrinas descem e saem marchando os melhores objetos, conduzidos pela foice e martelo, o pão e o sal, que encabeçam a comitiva, cercando-se dos portões".

Na seqüência os objetos manifestam-se dialogando:

"Objetos - E nós, nós os objetos ajudaremos o homem.

Nós os martelos, os agulhas, os serrotes ajudaremos os homens". As personagens humanas, uma vez desfeita a surpresa, passam a dialogar com as personagens objetos:

"Camponês - Camaradas Objetos! Sabem de uma coisa

Chega de torturar o destino. Agora, nós vamos construir você e vocês nos alimentar e se aparecer o patrão, não o deixaremos escapar com vida. Assim, viveremos melhor".

A partir deste encontro fazem pactos de ajuda e colaboração mútua:

"Camponês - Eu levaria um serrote. Faz tempo que não faço nada e sou jovem.

Serro te - Leve-me!

Costureira - E eu uma agulha. Agulha - Leve-me!

Ferreiro - Minha mão pede um martelo.

Martelo - Leve-me!"

E tudo termina com os trabalhadores, na peça denominados "Os Sujos". cantando a Internacional Socialista e expulsando "Os Limpos", ou seja, a classe dominante.

Maiakóvski propõe a invasão do palco por objetos comuns ao cotidiano dos homens. Os instrumentos de trabalho, alimento, constituem-se na presença arquetípica do objeto na esfera do comportamento e sobrevivência humana. O poeta convida seu público a sentir e perceber, através da forma inanima, fabricada industrialmente, porém, marcada pelas mãos dos homens, impulsos criativos, afetivos e simbólicos.

Quando o poeta russo recorre ao uso da animação de objetos estimula a imaginação e a fantasia do leitor/espectador, convidando-o a perceber que as coisas no mundo não precisam ser como sempre são e estão, que é preciso rever o sentido e estado das coisas. 
Algo semelhante acontece na peça "O Percevejo". O quinto ato da peça inicia com uma rubrica esclarecedora para a temática em estudo:

"Imensa sala de reuniões em forma de anfiteatro. Os homens são substituidos por alto-falantes. Junto destes, mãos de metal, do tipo dos indicadores de direção de automóveis. Por cima, lâmpadas de cor. Sob o teto, telas para projeção de imagens. Ao centro, uma tribuna com um microfone. À heira da tribuna, reguladores e botões de distribuição das vozes e das luzes. Dois mecânicos ᄀum jovem e um velho - trabalham na sala francamente iluminada ".

Numa das cenas deste ato, oportunidade em que há necessidade de se tomar uma decisão coletiva, os representantes das diversas regiões que compõem a "Federação da Terra" são apresentados como alto-falantes. Já numa outra situação deste mesmo ato, os homens são representados por mãos de ferro. Assim os homens são mãos de ferro, lâmpadas, alto $\neg$ falantes, ou seja, as coisas abandonam o seu lugar e uso cotidiano e ganham vida, atuam, decidem com, junto ou pelos homens.

Porém, na primeira peça escrita por Maiakóvski, a animação de formas e objetos acontece de maneira surpreendente, inusitada e sobretudo poética. Em "Vladimir Maiakóvski: uma tragédia", com exceção da personagem o poeta Maiakóvski, as demais são extraídas de um universo não naturalista, fragmentos de homens, mutiladas, como se fossem coisas saídas de um mundo onde objetos e formas são possuídas de vida.

As principais personagens da Tragédia são as seguintes: Vladimir Maiakóvski, um poeta (20 a 25 anos de idade); A Mulher Enorme, sua amiga (5 a 7 metros de altura, não fala); Velho com Gatos Negros e Magros (milhares de anos de idade); Homem Zarolho e Pemeta; Homem com Uma Orelha; Homem sem Cabeça; Homem de Cara Longa e Macilenta; Homem com Dois Beijos; Jovem Convencional; Mulher com Uma Lagrimazinha; Mulher com Uma Lágrima; Mulher com Uma Lagrimazona; Garotos Vendedores de Jornal; Beijos Infantis.

"As personagens concebidas por Maiakóvski são fragmentos de homens. Apresentam-se mutiladas, transformadas, como se fossem coisas. Para cada uma, falta-lhe determinada parte. A mutilação apresenta-se sob dois aspectos: um primeiro, de ordem física, na qual se realça a ausência de 
membros e outros órgãos do corpo, como perna, olho, cabeça e orelha. $\mathrm{O}$ segundo se dá pela manifestação hiperbólica da principal característica da personagem. Assim, o Homem com Dois Beijos, por exemplo, destaca sua mutilação emocional e afetiva através do realce dos beijos que lhe parecem inúteis" (Bolognesi, 1987, p.15).

"No primeiro ato, o poeta convoca e incita os mutilados para se rebelarem contra os burgueses. Deste incitamento, o Velho com Gatos Negros e Magros chama a atenção para a revolta dos objetos. E assim todo o primeiro ato transcorre em tomo da discussão sobre a natureza dos objetos, ou seja, se estes possuem ou não, uma alma. Ao final deste ato o Homem Zarolho e Pemeta vem anunciar a revolta das coisas, que está tomando conta da cidade" (Bolognesi,1987, p.21).

Um pequeno trecho da peça que ilustra a "humanização" dos objetos:

“...De repente,

todos os objetos fugiram,

rasgando a voz,

despojando-se de trapos de nomes obsoletos.

As janelas das casas de vinho,

como se incitadas por Satanás,

salpicaram o fundo das garrafas.

As calças fugiram

de um alfaiate desmaiado

e foram passear

sozinhas,

sem fundilhos humanos.

Uma cômoda bêbada, de pança boquiaberta

tropeçam dormitório afora.

Espartilhos temerosos de cair

dos anúncios "Robes et Modes ", choravam.

As galochas estavam severas e apertadas.

As meias, feito putas,

flertavam com os olhos.

Eu voei feito um palavrão.

Minha outra perna ainda tenta me alcançar:

está a um quarteirão" 
Como se vê, "as coisas abandonam o seu lugar e uso cotidianos, e ganham existência humana. Ao se tomarem autônomos, traduzem conteúdos e propriedades humanas. Neste caminho o texto apresenta a humanização dos objetos, uma expressão poética da coisificação dos homens. Há o deslocamento do foco de imagem, de sujeito para o objeto" (Bolognesi, 1987, p.23).

Nestas três peças: "Os Banhos", "O Percevejo" e "Vladimir Maiakóvski: uma tragédia”, o poeta propõe o uso de formas animadas ou a animação de objetos na cena. Ao dar vida aos objetos, ao humanizar as máquinas, propõe a reflexão sobre a inumanidade dos homens.

Tais objetos, transformados em personagens, são sintéticas, tipificadas, não têm aprofundamento psicológico, não representam um homem específico, mas o sentimento possível de ser reconhecido em todos os homens e mulheres. Por isso são arquetípicas, são máscaras que representam o mundo do trabalho, da sobrevivência, solidariedade, esperança e felicidade a ser consegui da com a Revolução.

\section{Reflexões finais}

É possível perceber a amplitude, densidade e complexidade da obra de Maiakóvski. Cada texto estudado trás uma infinidade de elementos que mostram a riqueza da obra e apontam para a necessidade de continuar estudando e se surpreendendo com a arte do poeta russo. As rupturas estéticas que fez com a arte 'teatral do seu tempo podem ser referências para a arte produzida contemporaneamente.

Tais inovações utilizadas com mais freqüência no teatro de bonecos dos últimos 30 anos, Maiakóvski já utilizava nos anos 10 e 20 do princípio do século XX. O emprego, na cena, de muitos e diferentes meios de expressão, procurando complementar e ampliar as expressões do boneco com a presença de diversos tipos de objetos, formas, máscaras e atores/personagens constituíam$\neg$ se em práticas comuns naquela época.

O palquinho tradicional, a tapadeira que historicamente cobria o manipulador e confinava o boneco àquele espaço restrito, foi demolido nas peças escritas por Maiakóvski. O ator-animador rompe com este espaço e passa ocupar um espaço cênico ilimitado. A "destruição" dessa tapadeira deixando à vista os atores-animadores inaugura um novo tipo de atuação. $\mathrm{O}$ bonequeiro deixa

\footnotetext{
${ }^{9}$ Tradução de Boris Schnaiderman e Nelson Ascher.
} 
de ser apenas o manipulador, para em cena, complementar a interpretação do boneco ou da forma animada.

Maiakóvski antecipa-se a tudo o que até então se fazia na área do teatro e principalmente do teatro de bonecos porque vai dar diferentes sentidos e conotações ao objeto animado na cena. Sem abandonar o boneco (forma antropomorfa), o poeta recorre a objetos cotidianos, cria novas formas, utensílio dando vida a cada uma delas.

Inspirado nas artes populares e nas tradições da commédia dell'arte circo e no teatro de bonecos Petrucka, Maiakóvski não faz simples transposição destas manifestações para a cena, mas as recria, reinventa dando atualidade estética às mesmas.

Revisitar a obra de Maiakóvski possibilita conhecer não só o teatro produzido naquela época como também, permite aprofundar os conhecimentos sobre o teatro de animação produzido contemporaneamente. Rever Maiakóvski estimula a produção de uma arte inquieta, irreverente, destituída de fórmulas prontas e comercialmente certeira. Encoraja a produção de uma arte poeticamente apaixonada pela vida e pelo futuro da humanidade.

Referências bibliográficas

AMARAL, Ana Maria. Teatro de formas animadas. São Paulo: EDUSP, 1991. BOLOGNESI, Mário. Tragédia: uma alegoria da alienação. Dissertação- Mestrado. São Paulo: ECA-USP, 19787.

BORBA FILHO, Hermíilo. Fisionomia e espírito do mamulengo. Rio de Janeiro: INACEN, 1987.

CARDOSO, Reni Chaves. Os banhos: uma poética em cena. Tese de Doutoramento São Paulo: FFLCH-USP, 1990.

O teatro de Maiakóvski. In: Revista da USP, n.19. São Paulo: set. novo 1993. CHESNAIS, Jacques. Histoire Général des Marionnettes. Paris: Éditions D' Aujourd'hui, 1980.

HORMIGON, Juan Antonio. Meyerhold: textos teóricos. Madrid: Publicaciones de Ia Asociación de Directores de Escena de Espana. 1992.

JURKOWSKI, Henryk. Consideraciones sobre el Teatro de Títeres. Bilbao: Concha de a Casa, 1990.

Écrivains et Marionnettes. Quatre Siécles de Littérature Dramatique. Cherleville-Mezieres: Institut International de la Marionnette, 1991. 
MAIAKÓVSKI, Vladimir. Yo o VIadimiro Maiakóvski. Tradução de Lila Guerrero. Buenos Aires: Editorial Platina, 1958.

Vladimir Maiakóvski: uma tragédia. Tradução de Nelson Ascher e rev. de Boris Schnaiderman. Datilografado.

Mistério Bufo. Tradução de Lila Guerrero. Buenos Aires: Editorial Platina, 1958.

Mistério Bufo. Tradução de Dmitri Beliaev. Rio de Janeiro: Musa, 2001.

Os banhos. Tradução de Luiz Sampaio Sacchi, rev. Boris

Schnaiderman. In: CARDOSO, Reni Chaves. Os banhos: uma poética em cena. Tese de Doutoramento. São Paulo: FFLCH-USP, 1990.

Moscou em chamas. Tradução de Luciano Fraga. São Paulo: Mimeo, 1993.

O percevejo. Tradução de Alexandre O’Neill. Lisboa: Editorial Presença, s./d.

OBRAZTSOV, Sergei. Mi Profesión. Moscou: Editorial Presença, 1950.

RIPELLINO, Angelo Maria. Maiakóvski e o teatro de vanguarda. São Paulo: Perspectiva, 1986.

TITIREANDO, Boletin Informativo de Ia Unión Internacional de la Marioneta-UNIMA Espana. ns.50 a 63. Tolosa, 1994 a 1957. 